\title{
Adenocarcinoma Arising in Warthin Tumor of the Parotid Gland
}

\section{Parotis Bezinde Warthin Tümörü Zemininde Gelişen Adenokarsinoma}

\author{
Hamide SAYAR ${ }^{1}$, Hüseyin ÖZTARAKÇI ${ }^{2}$, Çağdaş SAYAR ${ }^{3}$, Şule AĞIRBAŞ' \\ Department of Pathology, 'Kahramanmaraş Sütçü Imam University, Faculty of Medicine, KAHRAMANMARAŞ, TURKEY, \\ Department of Ear-Nose-Throat, ${ }^{2}$ M.D. Süreyya Adanalı Göksun State Hospital and ${ }^{3}$ Kahramanmaraş State Hospital, KAHRAMANMARAŞ, TURKEY
}

\begin{abstract}
Warthin tumor is a well-defined benign salivary gland neoplasm consisting of both epithelial and lymphoid components. The tumor is the second most common benign tumor next to pleomorphic adenoma. We present a case of adenocarcinoma, not otherwise classified, arising in unilateral Warthin tumor of the parotid gland in a 63-year-old male patient. Carcinomas arising in or from the epithelial component of a preexisting parotid Warthin tumor are rare and differential diagnosis of metastasis from an adenocarcinoma in Warthin tumor is important. The patient underwent a complete and thorough work-up, and no other primary malignant lesion was found. No other primary malignant lesion had manifested at the last one year follow-up period.
\end{abstract}

Key Words: Adenocarcinoma, Warthin tumor, Parotid gland, Salivary gland neoplasm

\section{INTRODUCTION}

Warthin tumor (WT), also known as papillary cystadenoma lymphomatosum or adenolymphoma, accounts for about $15 \%$ of all parotid tumors (1). The tumor is the second most common benign tumor after pleomorphic adenoma (2). WT is composed of glandular and papillary cystic structures with lymphoid tissue in the stroma. Malignant transformation of the lymphoid component is relatively common (3). However, epithelial malignancy in WT is extremely rare (1-9). The first case of carcinoma arising from WT was described by Ruebner and Bramhall in 1960 (8). To date, there have been limited case reports of carcinoma arising in WT of the parotid gland (1-9). This case report presents a case of adenocarcinoma, not otherwise classified (NOS), arising from WT of the right parotid gland.

\section{CASE REPORT}

A 63-year-old male presented with a pain lump in right infra-auricular region. It had been present for six months

(Turk Patoloji Derg 2012, 28:278-281)

Received : 09.12.2010 Accepted : 02.02.2011
ÖZ

Warthin tümörü epitelyal ve lenfoid bileşenden oluşan ve pleomorfik adenomdan sonra en sik görülen ikinci benign tükrük bezi tümörüdür. Sunduğumuz olgu parotis bezinde Warthin tümörü zemininde adenokarsinom (NOS) gelişen 63 yaşında erkek hastadır. Parotiste önceden var olan Warthin tümöründen adenokarsinom gelişimi nadirdir ve ayırıcı tanıda Warthin tümörüne adenokarsinom metastazı önemlidir. Hastanın tüm sistemik taramaları yapıldı ve başka bir primer malign lezyon bulunmadı. Hastada bir yıllık takip sonucunda başka primer malign lezyon da saptanmadı.

Anahtar Sözcükler: Adenokarsinoma, Warthin tümörü, Parotis tümörleri, Tükürük bezi neoplazileri

but had rapidly increased in size over the last 2 months. Physical examination revealed a 20x20 mm, relatively welldefined, tender mass in the right parotid gland. Full blood counts, biochemistry and chest x-ray were normal. The facial nerve was not involved. The patient had been healthy until this admission, with no history of surgery or chemoradiotherapy. Ultrasound examination revealed a $17 \times 17 \mathrm{~mm}$ solitary tumor mass in the right parotid gland. Magnetic resonance imaging revealed $14 \times 10 \mathrm{~mm}$ and $8 \times 5 \mathrm{~mm}$ lesions with well defined margins of the right parotid gland (Figure 1). A fine needle aspiration biopsy (FNAB) showed typical features of WT. In addition, there was a common area showing carcinomatous changes, with cells exhibiting an eosinophilic cytoplasm, atypical nuclei and prominent nucleoli (Figure 2). FNAB was therefore diagnosed and reported as suspicious of malignancy. The intra-operative examination of the parotid mass allowed us to diagnose the malignant tumor correctly and consequently undertake its radical excision.

Correspondence: Hamide SAYAR

Department of Pathology, Kahramanmaraş Sütçü İmam University,

Faculty of Medicine, KAHRAMANMARAŞ, TURKEY

E-mail: hamide1976@yahoo.com Phone: +90 344221 14 31, Ext: 377 


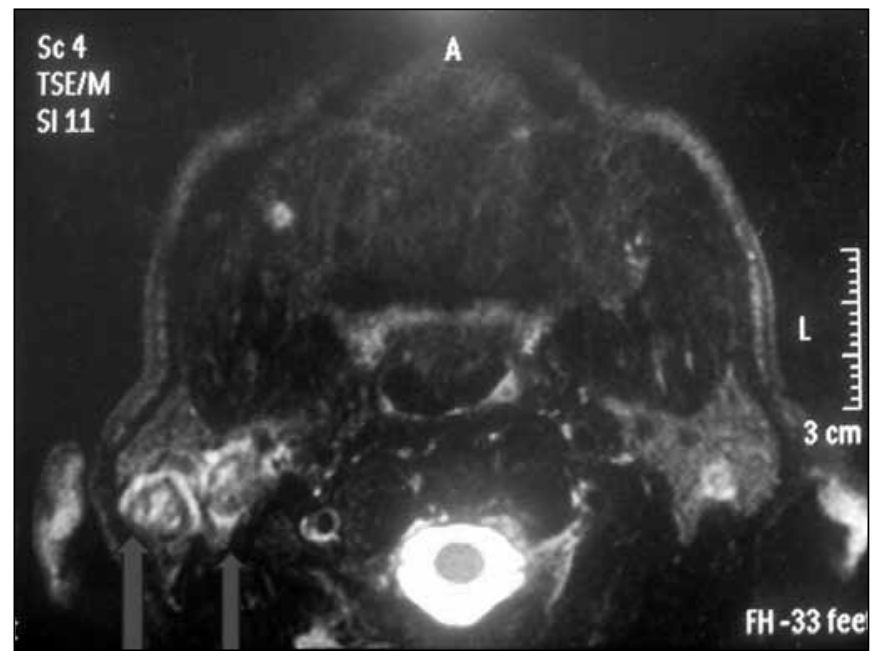

Figure 1: MRI showing a lesion located in the right parotid gland.

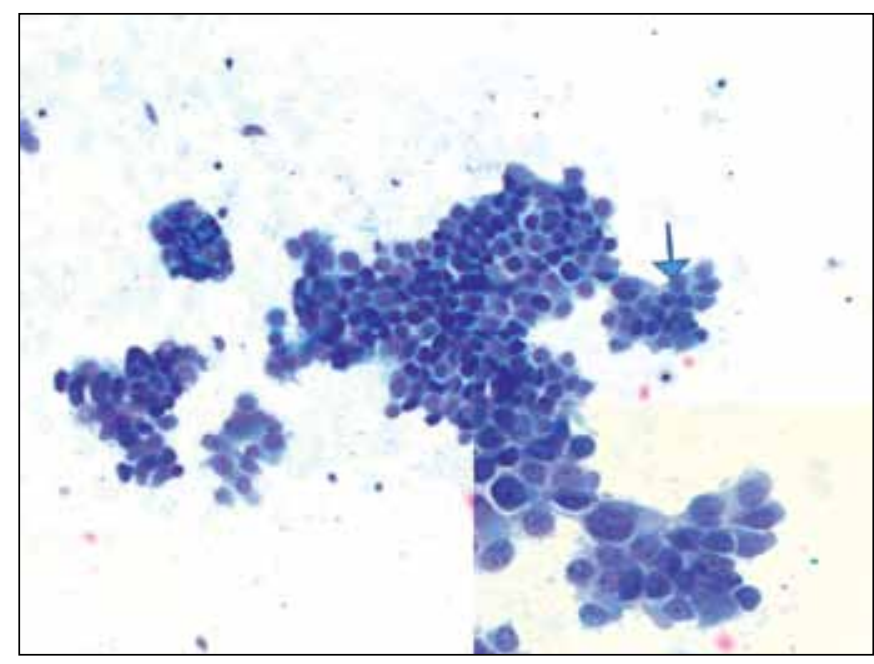

Figure 2: Warthin tumor of the parotid gland: Fine-needle aspiration reveals a fragment of metaplastic epithelium displaying cytologic atypia believed to be suspicious for malignancy. Note the background inflammatory cells (May-Grünwald-Giemsa, $\mathrm{x} 200$; inset, $\mathrm{x} 400$ ).

Total parotidectomy and right cervical lymphadenectomy were performed. The resected parotid tissue was $70 \times 30 \times 30$ $\mathrm{mm}$ in size, with a well-demarcated nodular tumor

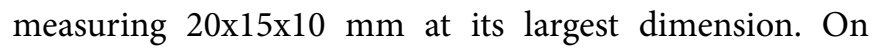
sectioning, the tumor was mostly solid, partially cystic, generally encapsulated, and it appeared grayish-white without necrotic foci or hemorrhage. Histologically, two different tumor elements were identified within the same mass (Figure 3). One part of the tumor showed the features of WT, composed of cystic spaces lined by oncocytic epithelial cells with some papillary projections and a partial typical double layered pattern as well as lymphoid stroma with lymphoid follicles. The other parts of the tumor showed features of adenocarcinoma that were characterized by glandular or ductal, focal papillary structures of atypical epithelial cells with apocrine snouts (Figure 4). Atypical epithelial cells were composed of cuboidalcolumnar shape, often with cells exhibiting an eosinophilic cytoplasm, atypical nuclei, prominent nucleoli, and mitosis. Microscopic examination showed transitional zones from benign oncocytic to frankly malignant epithelium (Figure 5).

Immunohistochemically cytokeratin 7 (CK), Pan-CK and Epithelial Membran Antigen (EMA) were equally positive both in benign and malignant epithelial cells (Figure 6). Ki67 proliferative index of adenocarcinoma cells and epithelial cells of WT was $20 \%$ and $3.0 \%$, respectively. Based on these

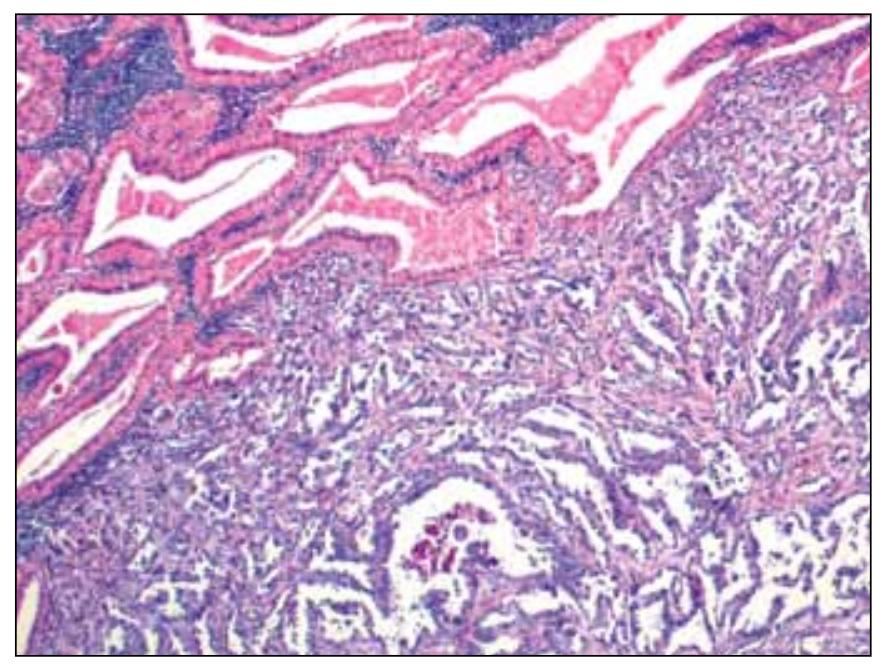

Figure 3: Low-power view of adenocarcinoma arising in Warthin tumor. Warthin tumor (upper portion) and invasive growth of adenocarcinoma (lower portion) are observed with close association between them (H\&E, x100).

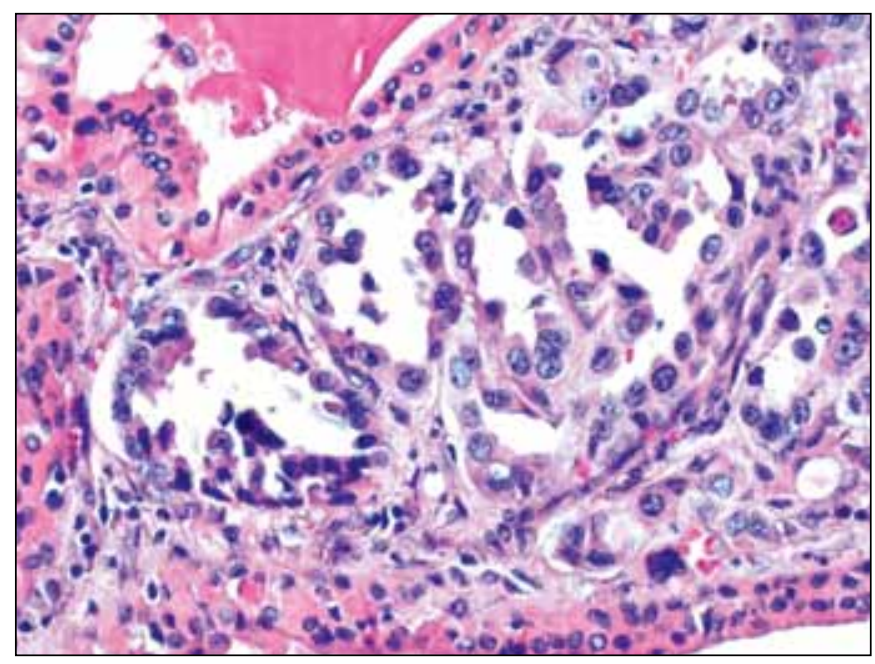

Figure 4: High-power view of the tumor. There were transitional features between adenocarcinoma and Warthin tumor $(\mathrm{H} \& \mathrm{E}$, $\mathrm{x} 400)$. 


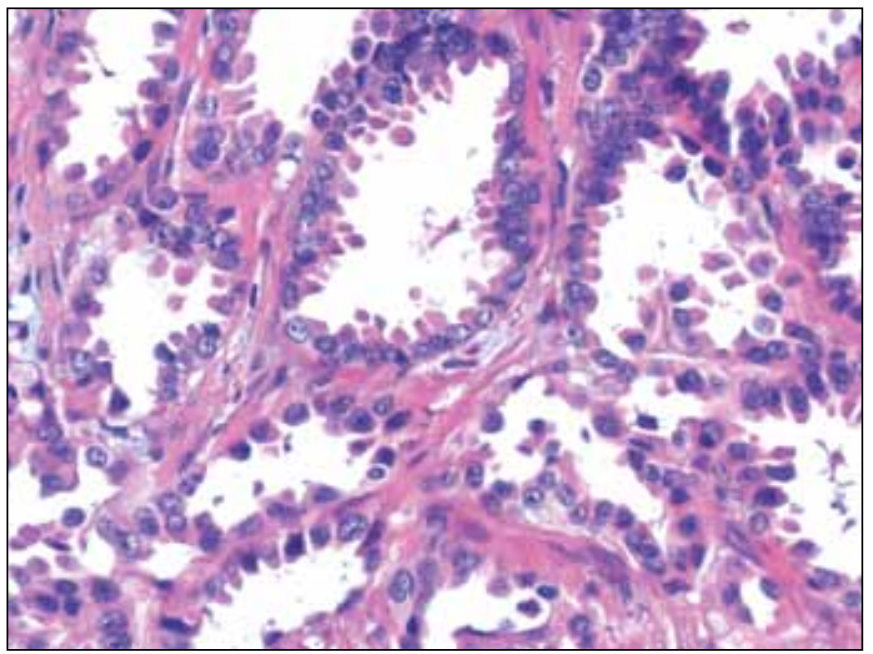

Figure 5: Photomicrograph showing the adenocarcinoma composed of glandular or ductal, focal papillary structures of atypical epithelial cells with apocrine snouts (H\&E, 400).

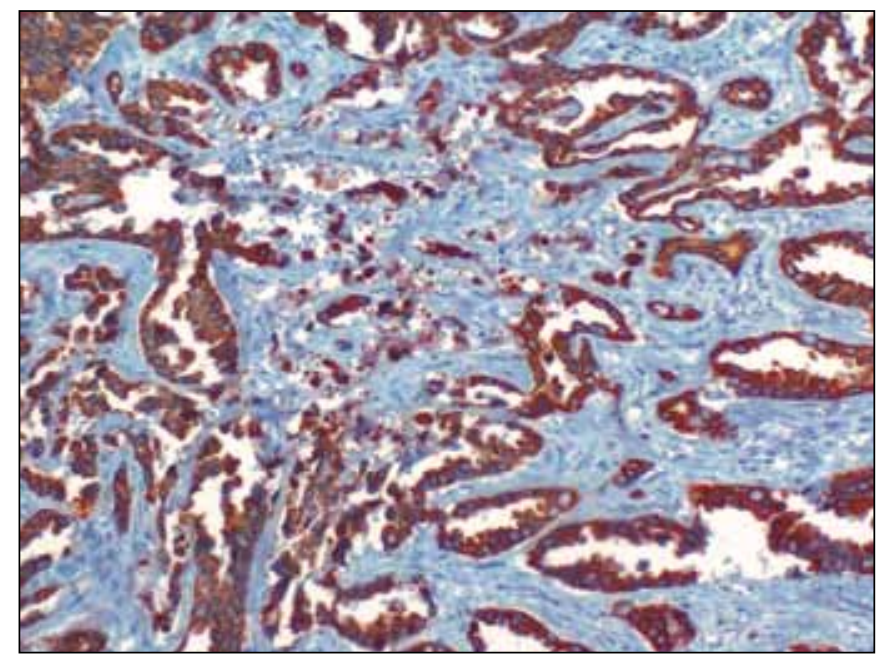

Figure 6: Immunohistochemical staining for cytokeratin 7 shows cytoplasmic staining in tumor cells of the adenocarcinoma (x200).

gross histological and immunohistochemical findings, the lesion was finally diagnosed as adenocarcinoma, not otherwise classified (NOS), arising in WT. Adenocarcinoma showed invasive growth into the adjacent surrounding parenchyma and fibrous connective tissue, but surgical margins were free of tumor cells. Perineural invasion was present but there was no evidence of vascular invasion. Lymph nodes obtained by the functional neck dissection were negative for neoplasm. The patient underwent postoperative radiotherapy. Follow-up of the patient after one year revealed no evidence of recurrence and metastatic neoplasm.

\section{DISCUSSION}

Warthin tumor is the second common benign salivary gland tumor (4). Most cases in the parotid gland involve the lower pole although $10 \%$ are in the deeper lobe. WT is multicentric in $12-20 \%$ of patients and is bilateral in $5-14 \%$ (3). The tumor almost always occurs in older adults. The peak incidence is in the 7th decade in males and the 6th decade in females. The tumor occasionally occurs in young patients. Most studies have found an average age at diagnosis in the early 60's as in our case (5).

The most popular theory for the pathogenesis of WT is that heterotopic salivary ducts which present in the pre-existing intraparotid or paraparotid lymphoid tissue (8). Our case had multiple lymph nodes in the parotid gland. Some of these lymph nodes were seen to have WT as a microscopical focus.

FNAB has good overall accuracy for diagnosing salivary gland neoplasms (87\% to 97\%) (5). A positive cytological diagnosis requires the distinct histologic elements of oncocytic epithelial cells in a lymphoid stroma. The morphological appearances are characteristic with cystic and solid areas composed of epithelial and lymphoid component. The nuclei of the epithelial cells were mostly regular and arranged in orderly double layers, but there were a few areas where there was glandular hyperplasia leading to a cribriform pattern with anisocytosis and nuclear pleomorphism. These areas were thought to be dysplastic and therefore regarded as transitional areas between the benign and malignant components.

The propensity for malignant transformation has been documented in the literature at a rate of $0.03 \%$ for all WT cases (2). The pathogenesis of the malignant transformation of WT is unknown $(1,2,8)$. Metaplasia to squamous or goblet cells occurring in the epithelial components of WT is a well-known feature and such a metaplastic WT accounted for $7.5 \%$ of the series described by Seifert et al. (10). These metaplastic changes also occur in normal parotid gland ducts that are believed to be the origin of carcinoma characterized by proliferation of epithelial cells showing dual squamous and mucous differentiation (8). The occurrence of adenocarcinomas of variable differentiation in WT is not surprising as oncocytic tumors show glandular differentiation with formation of luminal surfaces containing microvilli (1). In our case, the tumor did not show metaplastic changes.

There are less than 30 cases of different types of carcinoma arising in WT reported in the English literature (2). Squamous cell carcinoma and mucoepidermoid carcinoma have been reported as common types of carcinoma arising within WT. Other types of carcinoma arising in WT are 
oncocytic carcinoma, undifferentiated carcinoma and adenocarcinoma, not otherwise classified, as in our case (1-9).

The diagnosis of malignant transformation of WT to carcinoma is based on distinct criteria: (1) presence of a pre-existing benign WT; (2) presence of transitional zones from benign oncocytic to frankly malignant epithelium; (3) presence of an infiltrating growth in the surrounding lymphoid tissue; (4) exclusion of metastasis to lymphoid stroma from an extrasalivary primary carcinoma $(1,2,4)$. To distinguish metastasis from a primary carcinoma of another site, the presence of transitional zones from a benign oncocytic component to frankly malignant epithelium is also very important. Such a transition zone was shown in the present case.

Microscopically, adenocarcinoma (NOS) is composed only of a few cell types such as goblet, hobnail, apocrine and sebaceous cells. These cells are arranged with areas of glandular or ductal differentiation (6).

On standard magnetic resonance imaging, WT has certain characteristic features, including multifocal lesions and well defined margins (5).

The differential diagnosis of adenocarcinoma arising in WT includes metastatic adenocarcinoma to WT $(1,3)$. In our case, the metastasis to WT from a previous or synchronous malignant neoplasm involving a different anatomical site was excluded by the clinical history and physical examination. Finally, adenocarcinoma (NOS) was thought to arise in the WT.

Treatment of WT is adequate excision of the primary site with or without radical neck dissection. The long-term prognosis of these patients is not clear (8). We did not discover distant or lymph node metastases in our patient, and he was free of disease one year after treatment.
In conclusion, we have presented the clinicopathologic features of adenocarcinoma (NOS) arising in WT. WT is a benign lesion; however a very low rate of malignant transformation is recognized. FNAB cytological diagnosis and histopathological evaluation are necessary to detect malignant change in WT in the majority of parotid tumor cases.

\section{REFERENCES}

1. Perrotti V, Fioroni M, Corrado R: Adenocarcinoma arising in a Warthin's tumor. Oral Oncology Extra 2005,41:81-83

2. Bell D, Luna MA: Warthin adenocarcinoma: analysis of 2 cases of a distinct salivary neoplasm. Ann Diagn Pathol 2009,13:201-207

3. Sharma M, Chintamani, Saxena S: Squamous cell carcinoma arising in unilateral Warthin's tumor of parotid gland. JOMFP 2008, 12:82-84

4. Yamada S, Matsuo T, Fujita S, Suyama K, Yamaguchi A, Mizuno $A$ : Mucoepidermoid carcinoma arising in Warthin's tumor of the parotid gland. Pathol Int 2002, 52:653-656

5. Hatch RL, Shah S: Warthin Tumor: A common, benign tumor presenting as a highly suspicious mass. J Am Board Fam Pract 2005, 18:320-322

6. Li J, Wang BY, Nelson M, Li L, Hu Y, Urken ML, BrandweinGensler M: Salivary adenocarcinoma, not otherwise specified: a collection of orphans. Arch Pathol Lab Med 2004, 128:1385-1394

7. Ferrero S, Cattaneo L, Peri A, Braidotti P, Cioffi U, Scaramellini G, Ciulla MM, De Simone M, Arizzi C, Pignataro L: Poorly differentiated carcinoma arising from adenolymphoma of the parotid gland. BMC Surg 2003, 3:1-2

8. Nagao T, Sugano I, Ishida Y, Tajima Y, Furuya N, Kondo Y, Nagao K: Mucoepidermoid carcinoma arising in Warthin's tumour of the parotid gland: report of two cases with histopathological, ultrastructural and immunohistochemical studies. Histopathology 1998, 33:379-386

9. Bolat F, Kayaselcuk F, Erkan AN, Cagici CA, Bal N, Tuncer I: Epidermoid carcinoma arising in Warthin tumor. Pathol Oncol Res 2004, 10:240-242

10. Seifert G, Bull HG, Donath K: Histologic subclassification of the cystadenolymphoma of the parotid gland. Analysis of 275 cases. Virchows Arch A Pathol Anat Histol 1980, 388:13-38 